\title{
"Boyhood Masculinity and Violence": How Toys and Sporting Equipment Taught Men Violence in Canada, 1900-1950
}

\author{
Jocelyn Chugg
}

From the years 1900-1950 Canadian society had specific masculine beliefs that young boys were expected to live up to. By examining the toys and sporting equipment found throughout Sears Wishbook Christmas catalogues and comparing them with newspaper articles from that time it is clear that starting at a very young age, boys were subjected to various forms of violence in everyday life that was meant to ensure they grew up to be the tough, dominant and powerful men that were idolized in the first half of the $20^{\text {th }}$ century.

The late $19^{\text {th }}$ century was a time of mass urbanization in Canada. With technological advances in industry and manufacturing, more people were beginning to move to cities in an attempt to find work and take advantage of the growing Canadian economy. The change in lifestyle meant that there was also a growing change in gender ideologies. It was a concern that young boys who led sedentary urban lives were provided with "little opportunity for differentiation between the sexes." In most urban middle-class white families the father's role was that of the working breadwinner while the mother stayed home performing domestic duties and tending to the children. Many believed that boys, who were supposed to be tough, aggressive and competitive, were not given the appropriate opportunities to express their natural tendencies and those who spent too much time with their mothers ran the risk of becoming over feminized and "poorly adjusted children."

In an attempt to save boys from the crisis of masculinity that came with sedentary urban life and over-mothering, many middle-class men found new ways to practice and teach masculinity. One of the most popular ways for them to do so was through the sport of hunting. Gender historian Blake R. Brown suggests that "many Canadians both celebrated imperialism and saw hunting and rifle shooting as antidotes to the deleterious effects of modern urban life." 3 Brown also suggests that hunting, and more specifically shooting, was viewed as "a means to turn boys into men." "The value placed on hunting meant that there was one specific instrument that was becoming largely popularized as a symbol of manliness: the gun. Prior to the 1900s guns were used primarily as hunting and military equipment, but by the turn of the $20^{\text {th }}$ century, they were becoming desired consumer household items of the middle class. Guns were heavily marketed as "manly virtues" and new manufacturing technologies meant that they were being mass produced and sold at affordable prices. ${ }^{5}$ As the popularization of real guns increased, air rifles and toy guns started showing up in homes as a way to introduce young boys to the manly art of shooting.

${ }^{1}$ Blake R. Brown, “'Every boy ought to learn to shoot and to obey orders': Guns, Boys, and the Law in English Canada from the late Nineteenth Century to the Great War," The Canadian Historical Review 93, no. 2 (2012): 202.

${ }^{2}$ Mark Moss, Manliness and Militarism: Educating Young Boys in Ontario for War, (Don Mills: Oxford University Press, 2001), 111. Mona Lee Gleason, Normalizing the Ideal: Psychology, Schooling, and the Family in Postwar Canada, (Toronto: University of Toronto Press, 1999), 64.

${ }^{3}$ Brown, "Every boy ought to learn to shoot," 209.

${ }^{4}$ Brown, "Every boy ought to learn to shoot," 198.

${ }^{5}$ Ibid. 


\section{Chugg, "Boyhood Masculinity and Violence"48}

By the late 1930s, advertisements for toy guns were in abundance within magazines, newspapers and catalogues. Canadians encouraged young men to develop familiarity and skill with weapons, and toy guns were used to teach boys the mastery of hunting, shooting, and military skills without the risks that came with using real guns. ${ }^{6}$ The Sears Wishbook catalogues include several toy gun advertisements; many using specific imagery and language that reflected the beliefs of the idolized young men during this time. The guns in the catalogue were meant to look, act, and feel as real as possible. One such advertisement boasted on the realness of the gun by stating that it looked and sounded similar to the real thing, even including the "rat-a-tat noise" and sparks that mimicked real machine guns. ${ }^{7}$

During the early years of the Second World War, military-style toys were more prevalent

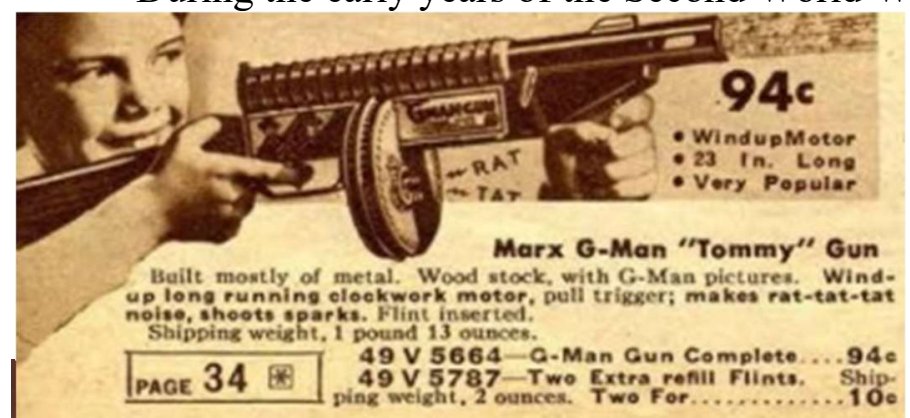
within the Sears catalogues. Not only was there a vast selection of this style of toy that was targeted at boys from toddler age up to adolescence, but they also begin to take on more of an educational role. They were marketed as instructive toys that would help boys better understand the act of war. One particular toy is a 75 piece set where boys could

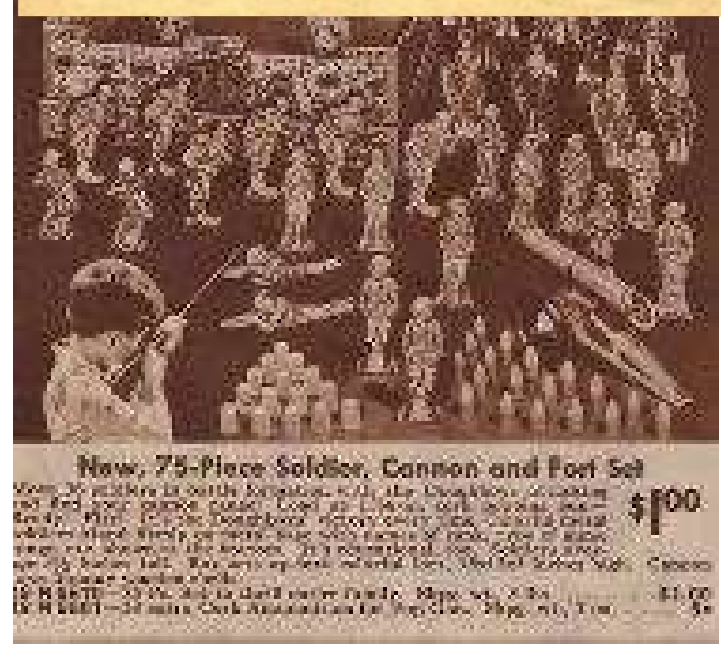
place soldiers in formation and shoot down their enemies with the included toy gun. Toys such as this one was manufactured to be so realistic that the army itself used them for training purposes. An article written in 1940 by an unknown author titled Big Set of Toy Soldiers Teaches Soldiers Army Tactics discusses how toys such as the ones found in Sears Catalogues were helpful in training exercises led by the actual military. ${ }^{8}$ At this time young boys were playing war with the same toys that were used by actual soldiers for teaching war.

Another noticeable feature found in the advertisements was the language used to glorify the acts of war. A toy in the 1943 catalogue called the "Exciting double-barreled Commando Gun"

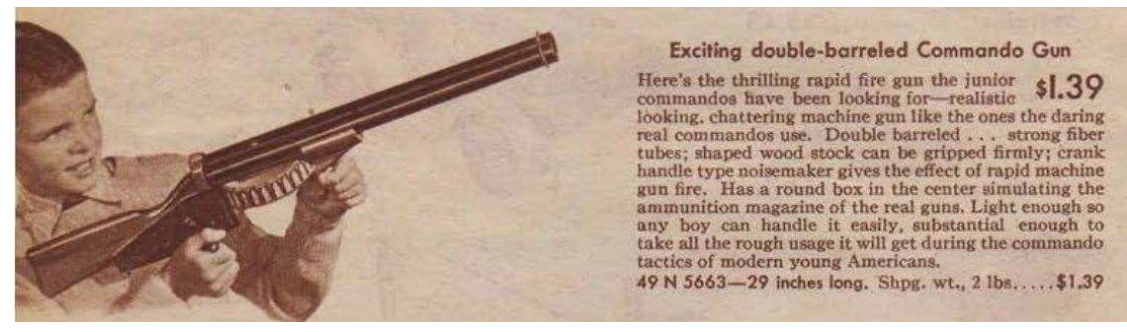
reads "here's the thrilling rapid-fire gun the junior commandos have been looking for- realistic looking, chattering machine gun like the ones the daring

\footnotetext{
${ }^{6}$ Brown, "Every boy ought to learn to shoot," 197.

7 "The Catalogues," 1937, Catch Themes, last Modified 2019, http://www.wishbookweb.com/FB/1937_Sears_Christmas_Book/\#36.

8 "Big Set of Toy Soldiers Teaches Army Tactics," The Globe and Mail (1936-Current), Feb 23, 1940, http://libproxy.mtroyal.ca/login?url=https://search-proquestcom.libproxy.mtroyal.ca/docview/1356070056? accountid=1343.
} 


\section{Chugg, "Boyhood Masculinity and Violence"48}

real commandos use."9 This was at a time when the war was broadcast to young Canadians in everyday life. The lives of the real commandos were being idolized and it was believed that "being a manly soldier meant taking charge, being a doer, and, most importantly, showing courage." ${ }^{10}$ Due to the introduction of toys such as the Commando Gun, young boys were now able to prove their bravery and strength by playing war with their friends.

This type of violent play was an acceptable way for boys to be able to express themselves in what was believed to be harmless fun. Christopher Dummitt discusses this in his book The Manly Modern. He states that the "socially utilitarian values of masculinity that had been so prominent during the Second World War" were assumed to have been successful in teaching young men the correct standards that were associated with becoming a man. ${ }^{11}$ It was with the help of violent toy guns, such as those found within the catalogues, that young boys were able to mimic the behaviours they saw taking place in real life through their play at home.

During the first half of the $20^{\text {th }}$ century, the psychology of parenting was becoming a highly studied field. Mona Lee Gleason is a gender historian and author of the book Normalizing the Ideal. She states that "it was during the interwar years that psychology carved a professional

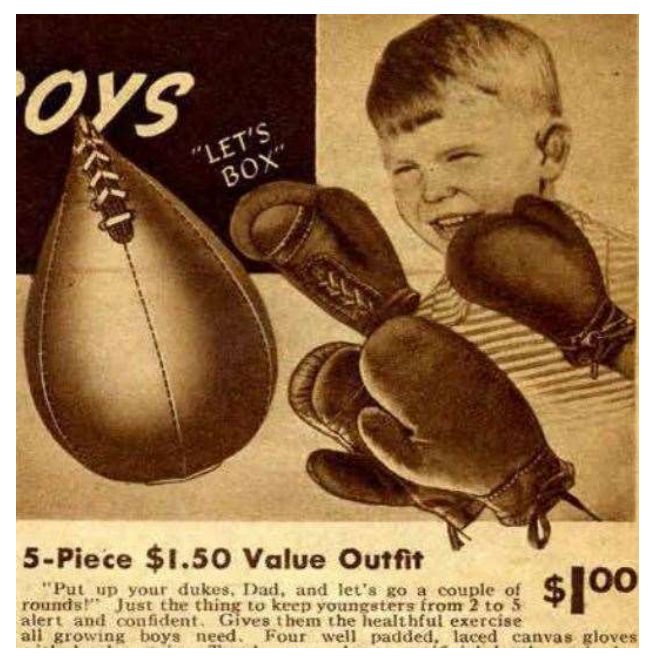
niche for itself' by studying the roles parents played in raising their children. ${ }^{12}$ Doctors based these gender roles on the lives of white middle-class patriarchal families and developed a "blueprint for normalcy" regarding young men to which they urged parents to follow. ${ }^{13}$ One way that they believed boys would have a better chance to develop into heterosexual men was to limit their time with their mothers and increase time spent with their fathers. Gleason states that "no longer were men just supposed to be providers, they should have a role in raising kids" as well. ${ }^{14}$ It was believed that a boy in the presence of his mother was a child, however, a boy in the presence of his father was a young man. ${ }^{15}$ One of the ways fathers could spend healthy time with their sons was through sport.

There are a number of advertisements for sporting equipment in the Sears catalogues that reflect this belief. Most notably is a five-piece boxing set from 1937. It states "Put up your dukes, Dad, and let's go a couple rounds!" demonstrate the role of the father during play, but it also proves how participating in violent

\footnotetext{
9 “The Catalogues," 1943, Catch Themes, last modified 2019, http://www.wishbookweb.com/FB/1943_Sears_Christmas_Book/\#72

${ }^{10}$ Moss, Manliness and Militarism, 114.

${ }^{11}$ Christopher Dummitt, The Manly Modern: Masculinity in Postwar Canada, (Vancouver: UBC Press, 2007), 19.

12 Gleason, Normalizing the Ideal, 5.

${ }^{13}$ Gleason, Normalizing the Ideal, 89.

${ }^{14}$ Gleason, Normalizing the Ideal, 69.

15 Ibid.

16 "The Catalogues," 1937, Catch Themes, last modified 2019, http://www.wishbookweb.com/FB/1937_Sears_Christmas_Book/\#32
} 


\section{Chugg, "Boyhood Masculinity and Violence"48}

sports such as boxing was viewed as an acceptable way for young boys to develop. The advertisement states that the boxing set is "just the thing to keep youngsters from 2 to 5 alert and confident." ${ }^{17}$ It was believed that boys should be participating in manly and violent sports beginning at a very young age in order to develop naturally. Fighting among boys "was often encouraged as a way of proving one's manliness" and during the first half of the $20^{\text {th }}$ century the sooner that lesson could be taught, the better. ${ }^{18}$

In his article Boys and Boyhood historian Christopher Greig describes the acceptable boyhood masculinity traits that were associated with sports. He states that "real boys were assumed to be developing normally if they were active and aggressive." 19 It was believed that there was a link between masculinity and violence and that males were naturally aggressive. ${ }^{20}$ Greig states that "violence in the form of fighting was simply a parental expectation, something an appropriate boy should do." ${ }^{21}$ He goes on to suggest that many believed that when confronted with a fight "a real boy would never run away" and "to do so would, and should they argued, raise questions about a boy's masculinity." 22 During a time where heterosexual beliefs were so strong, the act of fighting was viewed simply as a natural way for boys to prove their masculinity.

By the turn of the $20^{\text {th }}$ century more pressure was being put on society to produce the idolized version of the Canadian Man; one who was strong, fearless, and brave enough to fight not only for the protection of himself and his family, but also for his country. By encouraging violent masculine behaviour and pushing it onto young men, Canadian society normalized acceptable forms of violence to which males were expected to follow. With the popularization of toy guns and sporting equipment, boys were able to mimic the behaviours they witnessed through play. Emerging psychological discourse led to the belief that parents had to be taught how to raise their sons appropriately and through the persuasion of paternal involvement these behaviours would be passed down from generation to generation. It was through the acceptance and encouragement of violent play with the help of toys and sporting equipment that young boys were expected to conform to the ideals of masculinity within Canada during the first half of the $20^{\text {th }}$ century.

\footnotetext{
17 Ibid.

${ }^{18}$ Moss, Manliness and Militarism, 113.

${ }^{19}$ Christopher J. Greig, "Boys and Boyhood: Exploring the Lives of Boys in Windsor, Ontario, during the Postwar Era 1945-65," In Making Men, Making History: Canadian Masculinities across Time and Place, edited by Peter Gossage and Robert Rutherdale, 275.

${ }^{20}$ Dummitt, The Manly Modern, 115.

${ }^{21}$ Greig, Boys and Boyhood, 280.

${ }^{22}$ Grieg, Boys and Boyhood, 279.
} 


\section{Chugg, "Boyhood Masculinity and Violence"48}

\section{Bibliography}

"Big Set of Toy Soldiers Teaches Army Tactics." The Globe and Mail (1936-Current), Feb 23, 1940. http://libproxy.mtroyal.ca/login?url=https://search-proquestcom.libproxy.mtroyal.ca/docview/1356070056?accountid=1343.

Brown, R. Blake. “'Every boy ought to learn to shoot and to obey orders': Guns, Boys, and the Law in English Canada from the late Nineteenth Century to the Great War." The Canadian Historical Review 93 no. 2 (2012): 196-226.

Dummitt, Christopher. The Manly Modern: Masculinity in Postwar Canada. Vancouver: UBC Press, 2007.

Gleason, Mona Lee. Normalizing the Ideal: Psychology, Schooling, and the Family in Postwar Canada. Toronto: University of Toronto Press, 1999.

Greig, Christopher J. "Boys and Boyhood: Exploring the Lives of Boys in Windsor, Ontario, during the Postwar Era 1945-65. In Making Men, Making History: Canadian Masculinities across Time and Place, edited by Peter Gossage and Robert Rutherdale.

Greig, Christopher J. Ontario Boys: Masculinity and the Ideas of Boyhood in Postwar Ontario, 1945-1960. Waterloo: Wilfrid Laurier University Press, 2014.

Moss, Mark. Manliness and Militarism: Educating Young Boys in Ontario for War. Don Mills: Oxford University Press, 2001.

“The Catalogues!” Catch Themes. Last Modified 2019. http://www.wishbookweb.com/FB/1937_Sears_Christmas_Book/\#32.

“The Catalogues!" Catch Themes. Last Modified 2019. http://www.wishbookweb.com/FB/1937_Sears_Christmas_Book/\#36.

“The Catalogues!” Catch Themes. Last Modified 2019. http://www.wishbookweb.com/FB/1943_Sears_Christmas_Book/\#72. 